\title{
The relationship between mobile phone use and risk of brain tumor: a systematic review and meta-analysis of trails in the last decade
}

Lige Leng

\begin{abstract}
The aim of the present meta-analysis was to identify whether there was a relationship between mobile phone use and risk of brain tumor. A comprehensive search strategy was developed, and studies were eliminated in a stepwise manner, based on the inclusion criteria. The current meta-analysis collected data from the 24 eligible studies to investigate the relationship between mobile phone use and risk of brain tumor, while a detailed analysis of different classification was also conducted in order to identify the risk of mobile phone use. From the results, the relationship between cell phone use and brain tumor incidence had no significant difference between men and women. Cell phone use can increase the RF energy absorbed in the brain and apoptosis genes expression level, but glioma cell line cells were not significantly affected. Most calculations of laterality show a trend of increasing risk for time since first use, cumulative duration of subscriptions, cumulative duration of calls, and cumulative number of calls. In Asian people's, cell phone use and glioma had certain relations, while has very little relationship with meningioma incidence. This result seems to be no racial difference. In children and teenagers, cell phone use is associated with the incidence of brain tumors. We need longer time observation to supervise longer time (>20 years) mobile phone use whether has severe effects on incidence of brain tumor.
\end{abstract}

Keywords: Mobile phone use, Brain tumor, Glioma, Meningioma, Etiology

\section{Background}

With the rapid development of communication technology, mobile phones gradually began to rise from the mid - 1990s, and it is now very popular in many countries. Due to the invention of the various APP, people were more and more inseparable from the mobile phones. All aspects of life such as buying goods needed mobile phones to operate. Therefore, whether the using mobile phones harm human health had been received the widespread attention. Mobile phones made people exposed to highfrequency electromagnetic fields. People not only suffered their own mobile phone radiation, but also suffered the radiation due to large number of mobile phones used by other people, which almost made the world now an electromagnetic field. In July 28th 2014,

Correspondence: lenglige@xmu.edu.cn

Medical College, Xiamen University, Xiamen, Fujian Province 361102, People's Republic of China the United States survey organ-Strategy Analytics published, according to a report expected by the end of 2015, that global mobile phone users had been always close to 2.5 billion. In 2015, the world's population is expected to 7.2 billion, global mobile phone utilization rate will reach $34.7 \%$ (17.3).

For all the diverse high-frequency exposures occurring in environmental and occupational settings ranging from long-waves [a type of amplitude modulation (AM) broadcasting with carrier frequencies between 153 and $280 \mathrm{kHz}$ ] to radar waves. only a few long-term observational studies have been published (17.3). Because of the characteristics and the using methods of cell phone, the focus of attention gradually focused on the cell phone use and brain tumor risk. Many articles focus on this problem, however, the conclusion is contradictory. With the rapid development of nearly 10 years mobile phone usage, conclusions on this issue is also changing. But such 
discussions were very meaningful. In July 2011, The Lancet Oncology, the WHO's International Agency for Research on Cancer (IARC) declared that radiofrequency electromagnetic fields including mobile phone emit had bend classifyed as "possibly carcinogenic to humans" based on an increased risk of brain tumor including glioma and meningioma $[3,17,24]$. The move occured no more than a year after the huge Interphone study found no increased risk of cancer from more than a decade of mobile phone use. We tried to refine this big problem and tried to come to a conclusion with discussion and computed from different details.

The development of science and technology will surely bring some disadvantages. Whether these disadvantages will bring serious consequences is the mainly point that we need careful evaluation. Therefore, I discussed this problem from epidemiologic investigations to discuss the relationship between cell phone use and brain tumor incidence.

\section{Materials and methods}

Search strategy and selection criteria

In this meta-analysis, the recommendations of the Cochrane Handbook for Systematic Reviews of Interventions and the Quality of Reporting of Meta-Analyses statement were followed. A comprehensive search strategy was developed and the appropriate keywords were used. The databases searched included Medline, PubMed clinical trials, Web of Science (http://wok.mimas.ac.uk/), the Cochrane Database of Systematic Reviews, the Cochrane Central Register of Controlled Trials, Proceedings First and Papers First. In addition, conference proceedings, abstracts and the reference lists of other literature reviews and of all the short-listed studies were also searched. We scanned the relevant literatures in nearly decade.

\section{Data extraction and quality assessment}

Initially, 238 articles were identified from the databases used. Unsuitable articles were then eliminated in a stepwise manner, as shown in Fig. 1. First, any duplicates

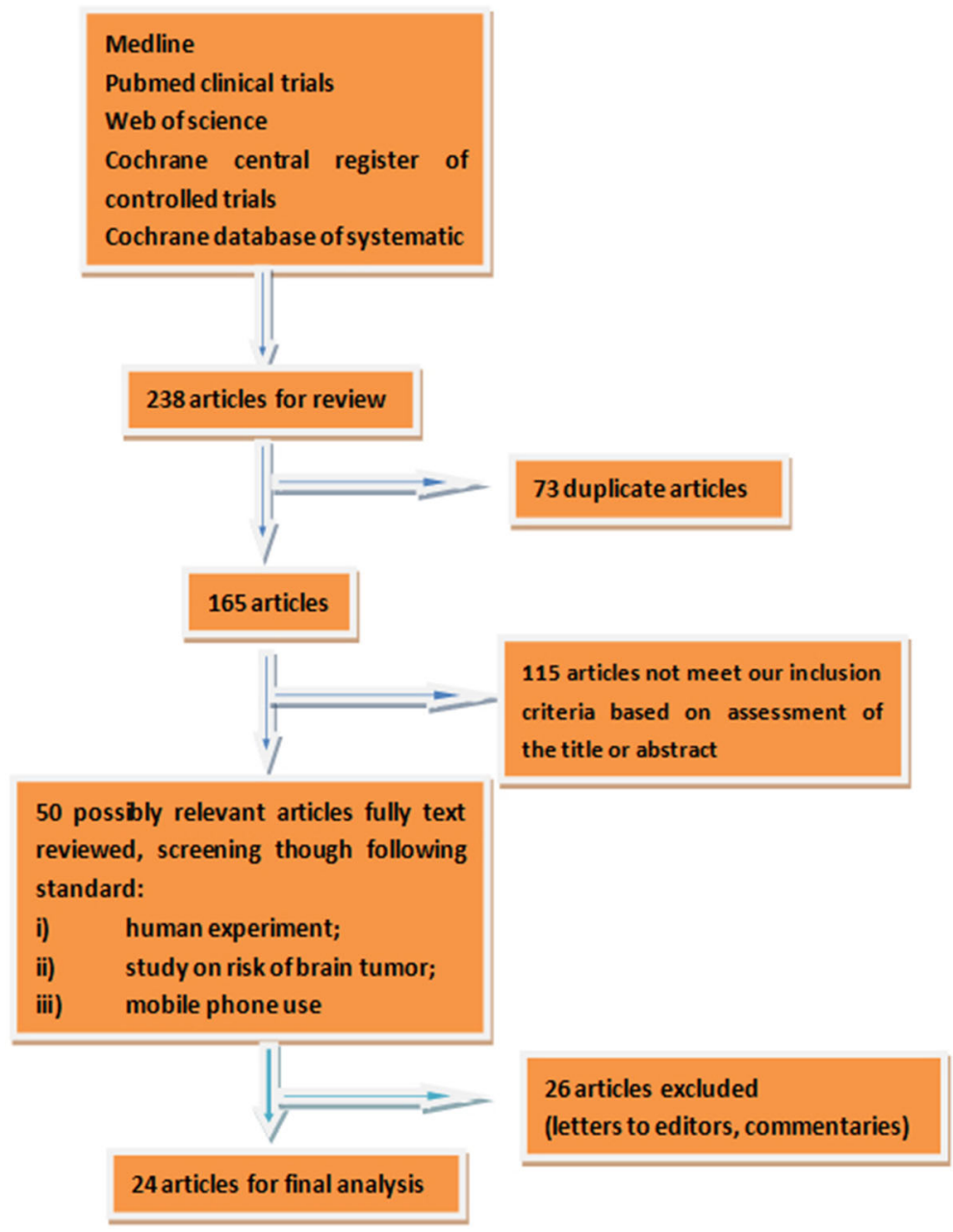

Fig. 1 Flow chart showing the process of article selection 
were excluded, followed by any evidently irrelevant articles that did not meet our inclusion criteria based on assessment of the title or abstract. The remaining articles were retrieved for full-text review by one reviewer and were short-listed for final review if the following criteria were met: i) published in peer-reviewed journals; ii) study on risk of brain tumor; and iii) included participants using MPs. The full text of all the articles that were short-listed at this stage was reviewed by two independent reviewers, according to an a priori protocol. Subsequently, the agreement of the two reviewers as to whether an article should be included was assessed as the ratio of studies where agreement was reached over the total studies assessed.

We have carried out a critical examination of the protocols and results from all case-control and cohort studies, pooled analyses and meta-analyses on head tumour risk among MP users. For each study we have identified the elements that must be taken into account to ensure an impartial evaluation of its reliability. The hypothesis test for presence of heterogeneity was based on the $\mathrm{Q}$ test of heterogeneity, which follows a $\chi^{2}$ distribution. Furthermore, two measures for quantifying the impact of heterogeneity were calculated: $\mathrm{H} 2$ (square root of the $\mathrm{Q}$ heterogeneity statistic divided by its degrees of freedom) and Higgins I2 (transformation of $\mathrm{H}$ that describes the proportion of total variation in study estimates that is due to heterogeneity). If heterogeneity was observed, then the random-effect model was performed by incorporating an estimate of the betweenstudy heterogeneity (DerSimonian and Laid t2) into the weights. When the general fixed effect model was applied to each study estimate, a weight directly proportional to its precision was given (inverse varianceweighted method).

\section{Statistical analysis}

Statistical analysis of the data extracted from each eligible study was performed using the Review Manager (RevMan) software version 5.0 for Windows (The Nordic Cochrane Centre, The Cochrane Collaboration, Copenhagen, Denmark). Due to significant clinical heterogeneity among the eligible studies, a random effects meta-analysis was performed in order to calculate the relative risk (RR) and absolute risk with the $95 \%$ confidence interval (CI) for mortality (if this was reported). In addition, the presence of statistical heterogeneity was investigated using the $\chi 2$ test and I2 value, with a priori-defined cutoff values of $P<0.10$ or I $2>50 \%$. If the cutoff values were exceeded, sensitivity analysis was performed to exclude any low-quality studies. Furthermore, funnel plots were constructed to assess the possibility of publication bias.

\section{Results \\ Eligible studies \\ Outcomes of eligible studies}

The summaries of these articles of on mobile phone use and brain tumor are in Table $1[1,2,4,5,7-12,14-16$, $18,20,21,23,25-31]$. In general, the conclusion of this article 24 is fraught with controversy and conflict, which can tell from the wide range of argument among author and readers after each article published. We can see that in the short term (10 years), the relationship between the application of mobile phones and brain tumors is not obvious. With the increasing of time ( $>10$ years), the dangerous of application mobile phone may gradually reveal. Mobile phone rapid developed in recent ten years, perhaps with the increasing of time ( $>20$ years), the risk of the using mobile phones will be highlighted.

(1) Different kinds of brain tumor The summaries of these articles of on mobile phone use and different kinds of brain tumor are in Table 2. The forest and funnel plot of mobile phone use and brain tumor were in Fig. $2(p>0.05)$.

1) Glioma

In glioma, the situation seems to be similar to the whole brain tumor, there were not any strong evidence showed that there was a relationship between glioma morbidity and mobile phone use $[2,4,8,9,11,16,23,27,30]$. But with the rising of glioma malignant degree, the level III to IV glioma seems to be associated with the use of mobile phone $[8,23]$.

2) Meningioma In meningioma $[2,4,9,11,16,23,30]$, The use of mobile phone does not increase the incidence of meningioma.

3) Acoustic tumor and pituitary tumor Because studies these two kinds of tumor are few, seems that cell phone use increased the incidence of acoustic tumor [2] while not much effect on incidence of pituitary tumor [30].

(2) Children and teenagers

The summaries of these articles of on mobile phone use and children and teenagers brain tumor are in Table 3. In children and teenagers, cell phone use is associated with the incidence of brain tumors [1, 10, 25, 28].

(3) Different racial types Asian The summaries of these articles of on mobile phone use and Asian people's brain tumor are in Table 4. Research $[29,30]$ shows that seems to Asian people's, cell phone use and glioma had certain relations, while has very little relationship with meningioma incidence. 
Table 1 Summary of studies on mobile phone use and brain tumor

\begin{tabular}{|c|c|c|c|c|c|}
\hline Study & $\begin{array}{l}\text { Period } \\
\text { covered }\end{array}$ & Study type & Age (years) & No.of cases & OR $(95 \% \mathrm{Cl})$ \\
\hline $\begin{array}{l}\text { Söderqvis et al., } 2011 \text { [28], } \\
\text { Nordic countries [4] }\end{array}$ & $2004-2008$ & Case-control & $7-19$ & 352 cases; 646 controls & $1.36 ;(0.92$ to 2.02$)$ \\
\hline Elliott et al., 2010 [10], UK [5] & 1999-2001 & Case-control & $0-4$ & 1397 cases: 5588 controls & $1.02(0.88$ to 1.20$)$ \\
\hline Takebayashi et al., 2006 [29], Japan [6] & 2000-2004 & Case-control & $30-69$ & 51 cases: 53 controls & 0.7 (0.4 to 1.2$)$ \\
\hline Takebayashi et al., 2008 [30], Japan [7] & 2000-2004 & Case-control & $30-69$ & 322 cases; 683 controls & $\begin{array}{l}1.22(0.63-2.37) \text { for glioma, } 0.70(0.42-1.16) \\
\text { for meningioma, and } 0.90(0.50-1.61) \text { for } \\
\text { pituitary adenoma }\end{array}$ \\
\hline Schüz et al., 2006 [26, 27], Denmark [8] & 1982-2002 & Cohort & $\geq 18$ & 32 & $0.7(0.5$ to 1.03$)$ \\
\hline $\begin{array}{l}\text { The INTERPHONE Study Group, } 2010 \text { [16], } \\
13 \text { countries [9] }\end{array}$ & 2000-2004 & Case-control & $30-69$ & $\begin{array}{l}2708 \text { glioma and } 2409 \text { meningioma } \\
\text { cases and matched controls }\end{array}$ & $\begin{array}{l}\text { glioma } 0.81(0.70-0.94) \text { and meningioma } 0.79 ; \\
(0.68-0.91)\end{array}$ \\
\hline Frei et al., 2011 [11], Danish [10] & 1990-2007 & cohort & $\geq 30$ & 10729 & $\begin{array}{l}\geq 13 \text { years } 1.03(0.83-1.27) \text { in men and } 0.91 \\
(0.41 \text { to } 2.04) \text { in women. } \\
\geq 10 \text { years, glioma } 1.04(0.85-1.26) \text { in men and } \\
1.04(0.56-1.95) \text { in women, meningioma } \\
0.90 \text { ( } 0.57 \text { to } 1.42) \text { in men and } 0.93(0.46-1.87) \\
\text { in women }\end{array}$ \\
\hline Deltour et al., 2009 [9], 4 countries [1 1] & 1974-2003 & cohort & $20-79$ & 59984 & $\begin{array}{l}\text { glioma } 1.05 \text { (0.98-1.08) among men and } 1.02 \\
(1.01-1.05) \text { among women; meningioma } 1.08 \\
(0.96-1.13) \text { among men, and } 1.38 \text { (1.32-1.44) } \\
\text { among women }\end{array}$ \\
\hline Schüz (b) et al., 2006 [26, 27], Germany [12] & 2000-2003 & Case-control & $30-69$ & $\begin{array}{l}366 \text { glioma cases, } 381 \text { meningioma } \\
\text { cases, and 1,494 controls }\end{array}$ & $\begin{array}{l}0.98(0.74-1.29) \text { for glioma and } 0.84(0.62-1.13) \\
\text { for meningioma. } \geq 10 \text { years, For glioma } 2.20, \\
(0.94-5.11) ; \text { for meningioma } 1.09(0.35-3.37)\end{array}$ \\
\hline Larjavaara et al., 2011, [18] 7 countries [13] & 2000-2004 & case-case analyses & $18-69$ & $\begin{array}{l}873 \text { glioma cases, with } 495 \text { being } \\
\text { regular mobile phone users and } 378 \\
\text { reporting no regular use. }\end{array}$ & no statistically significantly \\
\hline Little et al., 2012, USA [20] & 1997-2008 & cohort & $\geq 18$ & 24813 & $0.98(0.72-1.25)$ \\
\hline Inskip et al., 2010, [15] USA [15] & 1977-2006 & cohort & Not mentioned & 38788 & $\begin{array}{l}\text { Age } 20-29,1977-1991 \text { diagnosis } 2.52(1.31,3.76) ; \\
1992-2006 \text { diagnosis } 1.78(0.48,3.10)\end{array}$ \\
\hline Carlberg et al., 2013, [7] Sweden [16] & 2007-2009 & Case-control & $18-75$ & $\begin{array}{l}709 \text { meningioma cases and 1,368 } \\
\text { control subjects }\end{array}$ & $\begin{array}{l}\text { Mobile phone use 1.0 (0.7-1.4); cordless phone } \\
\text { use 1.1 (0.8-1.5) }\end{array}$ \\
\hline Carlberg et al., 2014, [8] Sweden [17] & $\begin{array}{l}1997-2003 \text { and } \\
2007-2009\end{array}$ & case-case analyses & $18-75$ & 1678 glioma cases & $\begin{array}{l}>20 \text { years For glioma } 1.7(1.2-2.3) \text {; astrocytoma } \\
\text { grade IV (glioblastoma multiforme; } n=926) \\
\text { Mobile phone use } 2.0(1.4-2.9) ; \text { cordless phone } \\
\text { use } 3.4(1.04-11)\end{array}$ \\
\hline Mild et al., 2007, [23] Sweden [18] & 1997-2003 & Case-control & $18-75$ & 2159 cases and 2162 controls & $\begin{array}{l}>10 \text { years, different kinds of brain tumor, } \\
\text { analogue phones yielded } 1.6,(1.02-2.5), \\
\text { digital phones } 1.3,(0.5-3.2) \text { and cordless } \\
\text { phones } 1.6,(0.9-2.8)\end{array}$ \\
\hline Hardell et al., 2013, [12] Sweden [19] & 2007-2009 & Case-control & $18-75$ & & $1.8(1.04-3.3)>25$ years $3.3(1.6-6.9)$ \\
\hline
\end{tabular}


Table 1 Summary of studies on mobile phone use and brain tumor (Continued)

\begin{tabular}{|c|c|c|c|c|c|}
\hline & & & & $\begin{array}{l}593 \text { malignant brain tumour cases, } \\
1368 \text { controls }\end{array}$ & \\
\hline Aydin et al., 2011, [1] 4 contries [20] & 2004-2008 & Case-control & $7-19$ & 352 cases and 646 controls & $1.36(0.92-2.02)>5$ years $1.26(0.7-2.28)$ \\
\hline Hepworth et al., 2006, [14] UK [21] & $2000-2004$ & Case-control & $18-69$ & 966 cases and 1716 controls & $0.94(0.78-1.13)$ \\
\hline Richard et al., 2014, [25] UK [22] & 2007-2009 & a pilot study & $0-24$ & 49 cases and 78 controls & $\begin{array}{l}\text { Response rates were } 52 \% \text { for cases and } 32 \% \\
\text { for controls. } \\
\text { Breastfeeding } 0.4(0.2-1.2) \text { Caesarean section } \\
1.6(0.6-4.4) \text {. }\end{array}$ \\
\hline Benson et al., 2013, [2] UK [23] & $\begin{array}{l}1999-2005 \text { and } \\
\text { again in } 2009\end{array}$ & cohort & middle-aged women & 791710 & $\begin{array}{l}1.01(0.9-1.4) \text { For glioma } 0.78,(0.55-1.10) \text {, } \\
\text { For meningioma } 1.10,(0.66-1.84) \text {, . For acoustic } \\
\text { neuroma, } 2.46,(1.07-5.64)\end{array}$ \\
\hline $\begin{array}{l}\text { Cardis et al., 2011, [5] five interphone } \\
\text { countries [24] }\end{array}$ & 2000-2004 & Case-control & $30-59$ & $\begin{array}{l}553 \text { glioma and } 676 \text { meningioma } \\
\text { cases and } 1762 \text { and } 1911 \text { controls }\end{array}$ & $\begin{array}{l}0.93 \text { ( } 0.73 \text { to } 1.18 \text { ) for glioma; } 0.80 \text { ( } 0.66 \text { to } 0.96 \text { ) } \\
\text { for meningioma }\end{array}$ \\
\hline $\begin{array}{l}\text { Cardis (b) et al., 2011, [5] five interphone } \\
\text { countries [35] }\end{array}$ & & $\begin{array}{l}\text { Estimation of RF energy } \\
\text { absorbed in the brain }\end{array}$ & & & \\
\hline Zhao et al., 2007 [31] [26] & & $\begin{array}{l}\text { Apoptosis Genes in } \\
\text { Primary Cultures of } \\
\text { Neurons and Astrocytes }\end{array}$ & & & \\
\hline Liu et al., 2015 [21] [27] & & $\begin{array}{l}\text { Study on cell lines, } \\
\text { U251-MG and U87-MG }\end{array}$ & & & \\
\hline
\end{tabular}


Table 2 Summary of studies on mobile phone use and different kinds of brain tumor (glioma, meningioma, acoustic neuroma, pituitary adenoma)

\begin{tabular}{|c|c|c|c|c|c|}
\hline Study & Period covered & Study type & Age (years) & No.of cases & OR $(95 \% \mathrm{Cl})$ \\
\hline \multicolumn{6}{|l|}{ Glioma } \\
\hline Takebayashi et al., 2008, [30] Japan [7] & 2000-2004 & Case-control & $30-69$ & 322 & $1.22(0.63-2.37)$ \\
\hline The INTERPHONE Study Group,2010, [16] 13countries [9] & 2000-2004 & Case-control & $30-69$ & 1078 & glioma $0.81(0.70-0.94)$ \\
\hline Frei et al.,2011, [11] Danish [10] & 1990-2007 & cohort & $\geq 30$ & 356 & $\begin{array}{l}1.04(0.85-1.26) \text { in men and } 1.04(0.56-1.95) \\
\text { in women }\end{array}$ \\
\hline Deltour et al., 2009, [9] 4 countries [11] & 1974-2003 & cohort & $20-79$ & 5390 & $\begin{array}{l}1.05 \text { (0.98-1.08) among men and } 1.02(1.01-1.05) \\
\text { among women }\end{array}$ \\
\hline Schüz (b) et al., 2006, [26, 27] Germany [12] & $2000-2003$ & Case-control & $30-69$ & 257 & $0.98(0.74-1.29) \geq 10$ years, 2.20, $(0.94-5.11)$ \\
\hline Carlberg et al., 2014, [8] Sweden [17] & $\begin{array}{l}1997-2003 \text { and } \\
2007-2009\end{array}$ & case-case analyses & $18-75$ & 1678 & $\begin{array}{l}>20 \text { years } \\
1.7(1.2-2.3) \text {; astrocytoma grade IV Mobile phone } \\
\text { use } 2.0(1.4-2.9) ; \text { cordless phone use } 3.4 \text { (1.04-11) }\end{array}$ \\
\hline Mild et al.,2007, [23] Sweden [18] & $1997-2003$ & Case-control & $18-75$ & 905 & $\begin{array}{l}>10 \text { years, grade I-II } 1.6(0.6-4.1) \text { grade III-IV } 2.7 \\
(1.8-4.2)\end{array}$ \\
\hline Benson et al., 2013, [2] UK [23] & $\begin{array}{l}1999-2005 \text { and } \\
\text { again in } 2009\end{array}$ & cohort & $\begin{array}{l}\text { middle-aged } \\
\text { women }\end{array}$ & 571 & $0.78,(0.55-1.10)$ \\
\hline Cardis et al., 2011, [5] five interphone countries [24] & 2000-2004 & Case-control & $30-59$ & 553 & 0.93 (0.73 to 1.18$)$ \\
\hline \multicolumn{6}{|l|}{ Meningioma } \\
\hline Takebayashi et al., 2008, [30] Japan [7] & $2000-2004$ & Case-control & $30-69$ & 322 & $0.70(0.42-1.16)$ \\
\hline The INTERPHONE Study Group,2010, [16] 13 countries [9] & $2000-2004$ & Case-control & $30-69$ & 1147 & $0.79 ;(0.68-0.91)$ \\
\hline Frei et al.,2011, [11] Danish [10] & 1990-2007 & cohort & $\geq 30$ & 80 & $\begin{array}{l}\geq 10 \text { years, } 0.90 \text { ( } 0.57 \text { to } 1.42) \text { in men and } 0.93 \\
(0.46-1.87) \text { in women }\end{array}$ \\
\hline Deltour et al., 2009, [9] 4 countries [11] & $1974-2003$ & cohort & 20-79 & 3175 & $\begin{array}{l}1.08 \text { (0.96-1.13) among men, and } 1.38 \\
(1.32-1.44) \text { among women }\end{array}$ \\
\hline Schüz (b) et al., 2006, [26, 27] Germany [12] & $2000-2003$ & Case-control & $30-69$ & 381 & $0.84(0.62-1.13) \geq 10$ years, $1.09(0.35-3.37)$ \\
\hline Benson et al., 2013, [2] UK [23] & $\begin{array}{l}1999-2005 \text { and } \\
\text { again in } 2009 .\end{array}$ & cohort & $\begin{array}{l}\text { middle-aged } \\
\text { women }\end{array}$ & 251 & $0.78,(0.55-1.10)$ \\
\hline Cardis et al., 2011, [5] five interphone countries [24] & $2000-2004$ & Case-control & $30-59$ & 676 & 0.80 (0.66 to 0.96$)$ \\
\hline Mild et al.,2007, [23] Sweden [18] & 1997-2003 & Case-control & $18-75$ & 759 & $1.3,(0.5-3.2)$ \\
\hline \multicolumn{6}{|l|}{ Acoustic Neuroma } \\
\hline Benson et al., 2013, [2] UK [23] & $\begin{array}{l}1999-2005 \text { and } \\
\text { again in } 2009\end{array}$ & cohort & $\begin{array}{l}\text { middle-aged } \\
\text { women }\end{array}$ & 96 & $2.46(1.07-5.64)$ \\
\hline \multicolumn{6}{|l|}{ Pituitary adenoma } \\
\hline Takebayashi et al., 2008, [30] Japan [7] & $2000-2004$ & Case-control & $30-69$ & 110 & $0.90(0.50-1.61)$ \\
\hline
\end{tabular}




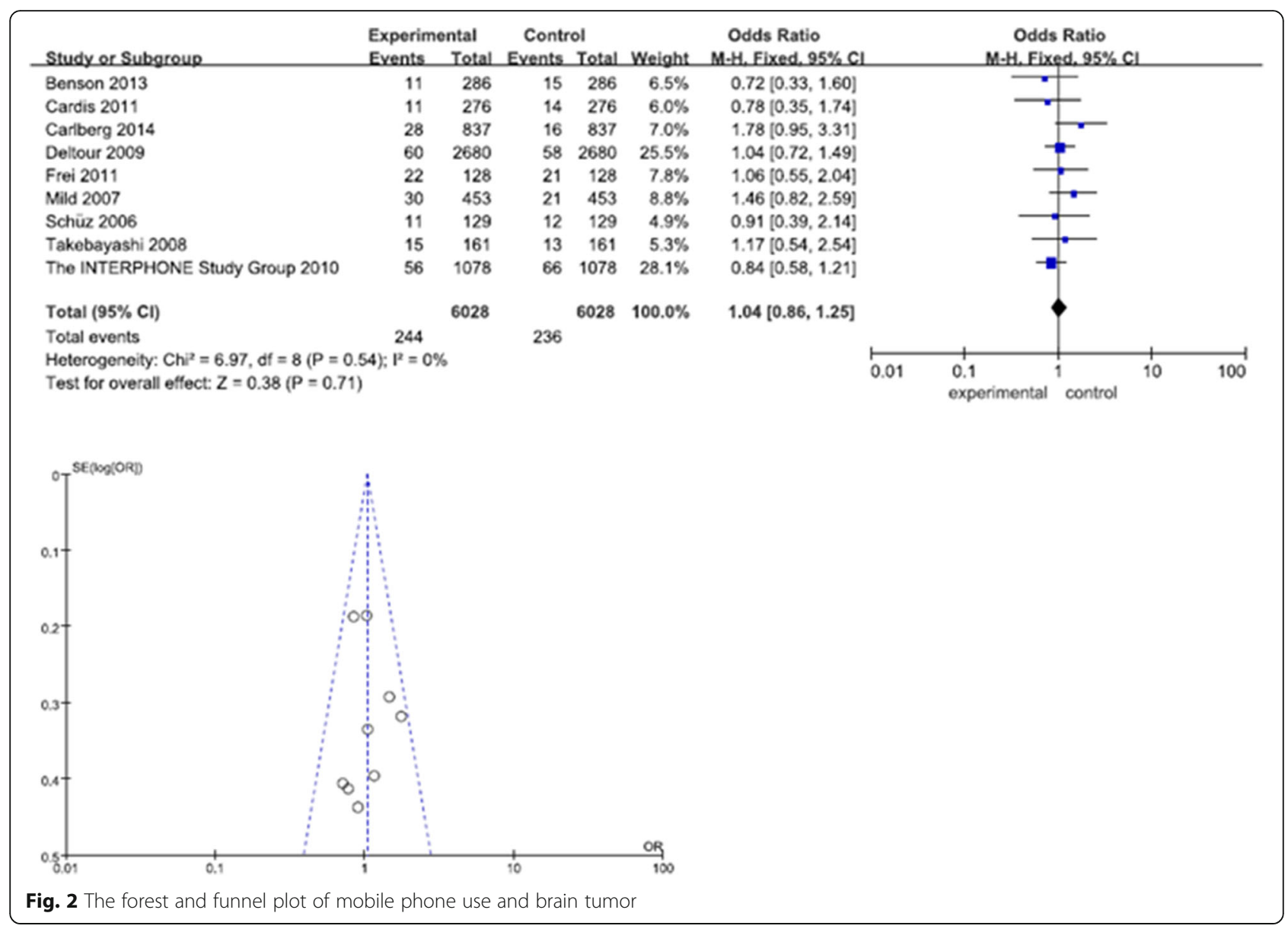

(4) Gender

The summaries of these articles of on mobile phone use and brain tumor on different gender are in Table 5. Research $[9,11]$ shows the relationship between cell phone use and brain tumor incidence had no significant difference between men and women.

(5) Cell, gene and tissue

A few articles on cells, genetic and RF energy absorbed in the brain showed [21,31] cell phone use can increase the RF energy absorbed in the brain and apoptosis genes expression level, but glioma cell line cells were not significantly affected.

\section{Discussion}

Methodologic problems

All these articles intends to evaluated from the aspect of analytical epidemiology and tried to estimate the risk of mobile phone use by application of some frequentlyused study types, such as case-control, and cohort study designs. Theoretically, all these study types are capable to detecting an existing risk under ideal conditions but actually they are influenced by many factors.

First of all, the time of using mobile phone and the distance of using mobile phone are hard to quantify. Some people might use mobile phone only one hour a day, while the others may want to use them all the time. Some

Table 3 Summary of studies on mobile phone use and children and teenagers brain tumor

\begin{tabular}{|c|c|c|c|c|c|}
\hline Study & $\begin{array}{l}\text { Period } \\
\text { covered }\end{array}$ & Study type & $\begin{array}{l}\text { Age } \\
\text { (years) }\end{array}$ & No.of cases & $\mathrm{OR}(95 \% \mathrm{Cl})$ \\
\hline $\begin{array}{l}\text { Söderqvis et al., 2011, [28] } \\
\text { Nordic countries [4] }\end{array}$ & $2004-2008$ & Case-control & $7-19$ & 352 cases; 646 controls & $1.36 ;(0.92$ to 2.02$)$ \\
\hline Elliott et al., 2010, [10] UK [5] & 1999-2001 & Case-control & $0-4$ & 1397 cases: 5588 controls & $1.02(0.88$ to 1.20$)$ \\
\hline Aydin et al., 2011, [1] 4 contries [20] & $2004-2008$ & Case-control & $7-19$ & 352 cases and 646 controls & $1.36(0.92-2.02)>5$ years $1.26(0.7-2.28)$ \\
\hline Richard et al., 2014, [25] UK [22] & 2007-2009 & a pilot study & $0-24$ & 49 cases and 78 controls & $\begin{array}{l}\text { Response rates were } 52 \% \text { for cases and } \\
32 \% \text { for controls. }\end{array}$ \\
\hline
\end{tabular}


Table 4 Summary of studies on Asian people's mobile phone use and brain tumor

\begin{tabular}{llllll}
\hline Study & $\begin{array}{l}\text { Period } \\
\text { covered }\end{array}$ & Study type & $\begin{array}{l}\text { Age } \\
\text { (years) }\end{array}$ & No.of cases & OR (95 \% Cl) \\
\hline Takebayashi et al., 2006, [29] Japan [6] & $2000-2004$ & Case-control & $30-69$ & 51 cases: 53 controls & 0.7 (0.4 to 1.2) \\
Takebayashi et al., 2008, [30] Japan [7] & $2000-2004$ & Case-control & $30-69$ & 322 cases; 683 controls & $\begin{array}{l}1.22 \text { (0.63-2.37) for glioma, 0.70 (0.42-1.16) } \\
\text { for meningioma, and 0.90 (0.50-1.61) for } \\
\text { pituitary adenoma }\end{array}$ \\
\hline
\end{tabular}

people may use the earphone, while some people don't. For people who use headphones, we don't know if it will be reached a safe distance.

Second, if using mobile phones has harm to human body, it will be a small but persistent effect. This effect may be accumulated decades before causing the occurrence of brain tumor. But using mobile phones developed rapidly in nearly 10 years, we really don't know whether such frequent using will lead a sharp rise in brain tumors in the future. Now, nearly 20 years, the incidence of brain tumors was slowly rising, with fluctuations up and down.

Third, there are many different kinds of brain tumor, including glioma, accounted for about half of the brain tumor. Different types of brain tumor have different cell source, therefore have different response to radiation. Simple discussing the relationship between the incidence of brain tumors and mobile phone use may lead to a vague conclusion.

\section{Potential biases}

Most studies were undergoing based on the Interphone protocol [6] that delimited regular use as more than one outgoing or incoming call per week for at least 6 months, with ever-regular use sustaining 1 year before the reference date. Although the reference date was defined as diagnosis date in cases and the same date of the matched control, in studies not individually matched. Because of the rapid increasing in mobile phone use during and before the study period, the methods used to compute the reference date for controls may be a source of bias.

Average power levels are not much different between cordless phones (average levels of $10 \mathrm{~mW}$ ) and mobile phones (median average output power 6-16 $\mathrm{mW}$ in urban areas). So the former should also be counted, different from Interphone group algorithm.
Method of data acquisition should be noted: a) interviews should be blinded to case status $r$; b) the interaction between interviewee and interviewer as such can lead to bias (Rosenthal effects); c) answering a questionnaire at home is less demanding may lead a bias; d) at home it is possible to check telephone bills or to inspect contracts with network providers to verify data. So face-to-face survey should be used instead of telephone survey, but due to the large numbers of survey, it's hard to do all the survey face-to-face. In some countries, the survey was conducted in the hospitals, while some of them are telephone surveys.these are all sources of bias. Different age groups and different cultures can also be the cause of bias, so we tried to reduce the bias through refine the $d$ investigation and group the investigation population.

\section{Results discussion}

Carcinogenesis is a multistage event and the tumorigenesis depends on initiation, promotion and progression of the disease. Since the mechanism for a possible tumorigenesis effect of RF-EMF exposure is unclear, descriptive incidence data are of limited value and should currently be less important to those based on analytical epidemiology. Further researches are need on the risk of brain tumors in children associated with use of mobile phones; future researches must accord with basic demands on quality, by which we mean not only efforts taken to ensure reliable assessment of results, but also to obtain a sufficient number of cases and controls of which not just a few by modern measures have been exposed. The specific mechanism by which RF-EMF exposure might cause cancer remains unclear. Since we lack that information, any hypothesis made about exposure-response relations and the threshold of any increased risk is immature. From the results, the relationship between cell

Table 5 Summary of studies on mobile phone use and brain tumor of different gender

\begin{tabular}{|c|c|c|c|c|c|}
\hline Study & $\begin{array}{l}\text { Period } \\
\text { covered }\end{array}$ & $\begin{array}{l}\text { Study } \\
\text { type }\end{array}$ & $\begin{array}{l}\text { Age } \\
\text { (years) }\end{array}$ & $\begin{array}{l}\text { No.of } \\
\text { cases }\end{array}$ & OR $(95 \% \mathrm{Cl})$ \\
\hline Frei et al., 2011, [11] Danish [10] & 1990-2007 & cohort & $\geq 30$ & 10729 & $\begin{array}{l}\geq 13 \text { years } 1.03(0.83-1.27) \text { in men and } 0.91(0.41 \text { to } 2.04) \\
\text { in women. } \\
\geq 10 \text { years, glioma } 1.04(0.85-1.26) \text { in men and } 1.04(0.56-1.95) \\
\text { in women, meningioma } 0.90(0.57 \text { to } 1.42) \text { in men and } 0.93 \\
(0.46-1.87) \text { in women }\end{array}$ \\
\hline Deltour et al., 2009, [9] 4 countries [11] & 1974-2003 & cohort & $20-79$ & 59984 & $\begin{array}{l}\text { glioma } 1.05 \text { (0.98-1.08) among men and } 1.02(1.01-1.05) \text { among } \\
\text { women; meningioma } 1.08 \text { (0.96-1.13) among men, and } 1.38 \text { (1.32-1.44) } \\
\text { among women }\end{array}$ \\
\hline
\end{tabular}


phone use and brain tumor incidence had no significant difference between men and women. Cell phone use can increase the RF energy absorbed in the brain and apoptosis genes expression level, but glioma cell line cells were not significantly affected. Most calculations of laterality show a trend of increasing risk for time since first use, cumulative duration of subscriptions, cumulative duration of calls, and cumulative number of calls. In Asian people's, cell phone use and glioma had certain relations, while has very little relationship with meningioma incidence. This result seems to be no racial difference. The severity and duration of prodromal symptoms are highly dependent on type of brain tumor; hence, such symptoms are unlikely to have occurred for long enough for the vast majority of the duration of exposure in most patients to explain the increased risk. It should also be pointed out that childhood tumors were totally different from adult tumors regarding their anatomy and histopathology. Moreover, one study on adults that presented results specifically for different types of glioma, e.g., low-grade and high-grade astrocytoma, indicated different risk patterns depending on the severity of the disease, with the highest risk being for highgrade astrocytoma. Most astrocytomas in children are of the low-grade type, relatively few being high-grade.

\section{Conclusion}

From the results, the relationship between cell phone use and brain tumor incidence had no significant difference between men and women. Cell phone use can increase the RF energy absorbed in the brain and apoptosis genes expression level, but glioma cell line cells were not significantly affected. Most calculations of laterality show a trend of increasing risk for time since first use, cumulative duration of subscriptions, cumulative duration of calls, and cumulative number of calls. In Asian people's, cell phone use and glioma had certain relations, while has very little relationship with meningioma incidence. This result seems to be no racial difference. In children and teenagers, cell phone use is associated with the incidence of brain tumors. We need longer time observation to supervise longer time ( $>20$ years) mobile phone use whether has severe effects on incidence of brain tumor.

\section{Abbreviations}

Cl: Confidence interval; IARC: International Agency for Research on Cancer; RR: Relative risk;

\section{Funding}

There is no funding for this review.

\section{Availability of data and materials Not applicable.}

\section{Author's contributions}

LL carried out the whole process which was from the conception to written. Only the authors listed on the manuscript contributed towards the article.

\section{Competing interests}

The authors declare that they have no competing interests.

\section{Consent for publication}

Not applicable.

Ethics approval and consent to participate

Not applicable.

Received: 18 July 2016 Accepted: 26 September 2016

Published online: 02 December 2016

References

1. Aydin $D$, Feychting $M$, Schüz J. Mobile phone use and brain tumors in children and adolescents: a multicenter case-control study. J Natl Cancer Inst. 2011;103(16):1264-2011.

2. Benson VS, Pirie K, Schüz J. Million women study collaborators. Mobile phone use and risk of brain neoplasms and other cancers: prospective study. Int J Epidemiol. 2013;42(3):792-802.

3. Boice Jr JD, Tarone RE. Cell phones, cancer, and children. J Natl Cancer Inst. 2011;103(16):1211-3

4. Cardis E, Armstrong BK, Bowman JD. Risk of brain tumours in relation to estimated RF dose from mobile phones: results from five interphone countries. Occup Environ Med. 2009;68(9):631-40.

5. Cardis E, Varsier N, Bowman JD. Estimation of RF energy absorbed in the brain from mobile phones in the interphone study. Occup Environ Med. 2011;68(9):686-93.

6. Cardis E, Richardson L, Deltour I. The INTERPHONE study: design, epidemiological methods, and description of the study population. Eur J Epidemiol. 2007;22(9):647-64.

7. Carlberg M, Söderqvist F, Hansson Mild K, Hardell L. Meningioma patients diagnosed 2007-2009 and the association with use of mobile and cordlessphones: a case-control study. Environ Health. 2013;12(1):60.

8. Carlberg M, Hardell L. Decreased survival of glioma patients with astrocytoma grade IV (glioblastoma multiforme) associated with long-term use of mobile and cordless phones. Int J Environ Res Public Health. 2014; 11(10):10790-805.

9. Deltour I, Johansen C, Auvinen A. Time trends in brain tumor incidence rates in Denmark, Finland, Norway, and Sweden, 1974-2003. J Natl Cancer Inst. 2009;101(24):1721-4

10. Elliott P, Toledano MB, Bennett J. Mobile phone base stations and early childhood cancers: case-control study. BMJ. 2010;340:c3077.

11. Frei $P$, Poulsen $A H$, Johansen C. Use of mobile phones and risk of brain tumours: update of Danish cohort study. BMJ. 2011;343:d6387.

12. Hardell L, Carlberg M, Söderqvist F, Mild KH. Case-control study of the association between malignant brain tumours diagnosed between 2007 and 2009 and mobile and cordless phone use. Int J Oncol. 2013;43(6):1833-45.

13. Hardell L, Carlberg M, Söderqvist F. Long-term use of cellular phones and brain tumours: increased risk associated with use for $\geq 10$ years. Occup Environ Med. 2007:64(9):626-32.

14. Hepworth SJ, Schoemaker MJ, Muir KR. Mobile phone use and risk of glioma in adults: case-control study. BMJ. 2006;332(7546):883-7.

15. Inskip PD, Hoover RN, Devesa SS. Brain cancer incidence trends in relation to cellular telephone use in the United States. Neuro Oncol. 2010;12(11): $1147-51$.

16. INTERPHONE Study Group. Brain tumour risk in relation to mobile telephone use: results of the INTERPHONE international case-control study. Int J Epidemiol. 2010;39(3):675-94.

17. Kundi $\mathrm{M}$. The controversy about a possible relationship between mobile phone use and cancer. Environ Health Perspect. 2009;117(3):316-24.

18. Larjavaara S, Schüz J, Swerdlow A. Location of gliomas in relation to mobile telephone use: a case-case and case-specular analysis. Am J Epidemiol. 2011;174(1):2-11.

19. Levis AG, Minicuci N, Ricci P. Mobile phones and head tumours. The discrepancies in cause-effect relationships in the epidemiological studies - how do they arise? Environ Health. 2011;10:59.

20. Little MP, Rajaraman P, Curtis RE, Devesa SS, Inskip PD, Check DP, Linet MS. Mobile phone use and glioma risk: comparison of epidemiological study results with incidence trends in the United States. BMJ. 2012;344:e1147.

21. Liu YX, Li GQ, Fu XP. Exposure to $3 G$ mobile phone signals does not affect the biological features of brain tumor cells. BMC Public Health. 2015;15:764. 
22. Lönn S. Mobile phone use and risk of intracranial tumors [doctoral thesis]. Stockholm: Karolinska Institutet; 2004.

23. Mild KH, Hardell L, Carlberg M. Pooled analysis of two Swedish case-control studies on the use of mobile and cordless telephones and the risk of brain tumours diagnosed during 1997-2003. Int J Occup Saf Ergon. 2007;13(1):63-71.

24. Peres J. WHO classification sparks debate over cell phone safety. J Natl Cancer Inst. 2011;103(15):1146-7.

25. Feltbower RG, Fleming SJ. UK case control study of brain tumours in children teenagers and young adults: a pilot study. BMC Res Notes. 2014;7:14.

26. Schüz J, Jacobsen R, Olsen JH. Cellular telephone use and cancer risk: update of a nationwide Danish cohort. J Natl Cancer Inst. 2006;98(23):1707-13.

27. Schüz J, Böhler E, Berg G. Cellular phones, cordless phones, and the risks of glioma and meningioma (interphone study group, Germany). Am J Epidemiol. 2006;163(6):512-20.

28. Söderqvist F, Carlberg M, Hansson Mild K, Hardell L. Childhood brain tumour risk and its association with wireless phones: a commentary. Environ Health. 2011;10:106.

29. Takebayashi T, Akiba S, Kikuchi Y. Mobile phone use and acoustic neuroma risk in Japan. Occup Environ Med. 2006;63:802-7.

30. Takebayashi T, Varsier N, Kikuchi Y. Mobile phone use, exposure to radiofrequency electromagnetic field, and brain tumour: a case-control study. Br J Cancer. 2008;98(3):652-9.

31. Zhao TY, Zou SP, Knapp PE. Exposure to cell phone radiation up-regulates apoptosis genes in primary cultures of neurons and astrocytes. Neurosci Lett. 2007;412(1):34-8.

\section{Submit your next manuscript to BioMed Central} and we will help you at every step:

- We accept pre-submission inquiries

- Our selector tool helps you to find the most relevant journal

- We provide round the clock customer support

- Convenient online submission

- Thorough peer review

- Inclusion in PubMed and all major indexing services

- Maximum visibility for your research

Submit your manuscript at www.biomedcentral.com/submit 